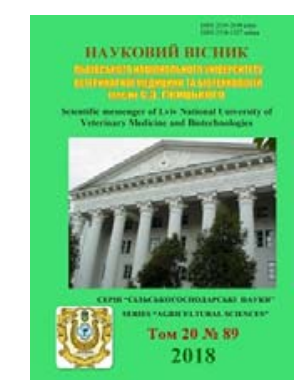

UDC 636.2.034.082

\section{Науковий вісник Дьвівського національного університету ветеринарної медицини та біотехнологій імені С.3. Гжицького}

\author{
Scientific Messenger of Lviv National University \\ of Veterinary Medicine and Biotechnologies
}

ISSN 2519-2698 print

doi: $10.32718 /$ nvlvet8921

ISSN 2518-1327 online

\title{
Reproductive ability of cows and their descendants of different generations
}

\author{
S.I. Fyl ${ }^{1}$, E.I. Fedorovych ${ }^{2}$, P.V. Bodnar ${ }^{3}$ \\ ${ }^{1}$ Institute of Animal Breeding and Genetics nd. a. M.V. Zubets of National Academy of Agrarian Science of Ukraine \\ ${ }^{2}$ Institute of animal biology NAAS, Lviv, Ukraine \\ ${ }^{3}$ Stepan Gzhytskyi National University of Veterinary Medicine and Biotechnologies Lviv, Ukraine
}

\section{Article info}

Received 22.09.2018

Received in revised form 24.10.2018

Accepted 25.10.2018

Institute of Animal Breeding and Genetics nd. a. M.V. Zubets of National Academy of Agrarian Science of Ukraine, Pohrebnyaka Str., 1, Chubynske, Boryspil region Kyiv district, 08321, Ukraine

Institute of animal biology NAAS, Vasyl Stus Str., 38, Lviv, 79034, Ukraine.

Tel.: +38-032-270-23-89

E-mail:logir@ukr.net

Stepan Gzhytskyi National University of Veterinary Medicine and Biotechnologies Lviv, Pekarska Str., 50, Lviv, 79010, Ukraine.
Fyl, S.I., Fedorovych, E.I., \& Bodnar, P.V. (2018). Reproductive ability of cows and their descendants of different generations. Scientific Messenger of Lviv National University of Veterinary Medicine and Biotechnologies, 20(89), 114-121. doi: 10.32718/nvlvet8921

The research was carried out on cows of Ukrainian Black-and-White Dairy breed and their descendants of the first and second generations on the conditions of LLC "Veletenj" in the Glukhiv district of the Sumy region. In cows, based on a retrospective analysis of data and the results of their own searches, was studied the age dynamics of reproductive capacity of cows for the first-seventh and higher lactation, and their daughters and granddaughters for the first and higher lactation. It has been established that reproductive ability of cows to some extent is due to their age. Depending on the lactation, the duration of the parturition of the cows of LLC "Veletenj" varied from 278.2 to 280.0, the duration of the indifference periodfrom 64.4 to 69.0 days, service period - from 123.5 to 136.4, inter-calving period-from 402.2 to 414.8 and in the dry stable period - from 61.3 to 75.8 days, the reproduction rate was $0.91-0.93$, the calves output for 100 cows was 90.9-93.0 the index of insemination is 2.41-2.56 and the fertility index is 42.2-44.8. The results of our research indicate that each subsequent generation of cows was characterized by a better reproductive ability, which, in our opinion, is due to the timely abandonment of fetuses and stimulation of infertile cows, as well as an improved level of feeding. The difference in the duration of the service period for the first lactation between the mothers and their daughters was 24.5, for the best lactation-24.8, for the duration of the interotional period -24.8 and 23.7 days, respectively, at $P<0.001$ in all cases. A more significant difference in reproductive performance was observed between cows and their granddaughters. In terms of the duration of the service period for the first and best lactation, it was $15.5(P<0.05)$ and 33.3 $(P<0,001)$ and interotional period $-17.3(P<0.05)$ and 33,2 days $(P<0.001)$ respectively. Between the majority of the studied reproductive abilities of mothers and daughters for the first and higher lactation, the relative variability was positive and reliable, and mothers and granddaughters - low uncertainty and mostly negative (exception - the duration of calving). The highest positive correlation coefficients were observed between the duration of cervix and their daughters $(r=0.113 \pm 0.039$ at $P<0.001)$ and granddaughters $(r=0.211 \pm 0.088$ at $P<0.05)$ for the first lactation, as well as mothers and daughters for higher lactation $(r=0.114 \pm 0.039$ at $P<0.01)$. Between indicators of the indifference period $(r=-0.036-0.051)$ and the index of fertility of cows ( $r=-0.080-0.014)$ and their descendants for the lactation under investigation have low, multidirectional, unreliable connections. The influence of mothers on indicators of reproductive function of descendants is established. They made the most significant impact on the duration of service and inter calving periods, reproduction rate, calving out of 100 cows and the index of daughter insemination ( $\eta_{x}{ }^{2}$ $=27.57-52.22 \%$ ). For higher lactation, this effect was significantly lower (exception - the index of insemination) $-\eta_{x}^{2}=15,39-28,10 \%$.

Key words: cows, daughters, granddaughters, indicators of reproduction ability, correlation coefficients, impact strength.

\section{Відтворювальна здатність корів та їх нащадків різних поколінь}

\author{
С.І. Филь ${ }^{1}$, С.І. Федорович ${ }^{2}$, П.В. Боднар ${ }^{3}$
}

${ }^{1}$ Інститут розведення і генетики тварин імені М. В. Зубия НААН, с. Чубинське, Бориспільський р-н Київська обл., Україна

${ }^{2}$ Інститут біології тварин НААН, м. Львів, Украӥна

${ }^{3}$ Львівський національний університет ветеринарної медицини та біотехнологій імені С.3. Гжсицького, 


\section{м. Львів, Україна}

Дослідження проведені на коровах украӥнської чорно-рябої молочної породи та їх нащадках першого і другого поколінь в умовах ТОВ “Велетень" Глухівського району Сумської області. У корів, на основі ретроспективного аналізу даних та результатів власних досліджень, вивчали вікову динаміку відтворювальної здатності корів за першу-сьому та вищу лактаиії, а у їх дочок $і$ внучокза периу та вищу лактаиії. Встановлено, що відтворювальна здатність корів певною мірою зумовлена їх віком. Залежно від лактаиії, тривалість тільності у корів ТОВ “Велетень" коливалася від 278,2 до 280,0, тривалість індиференс-періоду - від 64,4 до 69,0 дня, сервіс-періоду - від 123,5 до 136,4, міжотельного періоду - від 402,2 до 414,8 та сухостійного періоду - від 61,3 до 75,8 дня, коефіџієнт відтворювальної здатності становив 0,91-0,93, вихід телят на 100 корів - 90,9-93,0 гол., індекс осіменіння - 2,412,56 та індекс плодючості - 42,2-44,8. Результати наших досліджень свідчать, щю кожне наступне покоління корів відзначалося кращою відтворювальною здатністю, що, на нашу думку, пояснюється своєчасним вибракуванням ялових та стимуляиією неплідних корів, а також покращеним рівнем годівлі. Різниия за тривалістю сервіс-періоду за першу лактацію між матерями та їх дочками становила 24,5, за кращу - 24,8, за тривалістю міжотельного періоду - 24,8 та 23,7 дня відповідно при $P<0,001$ в усіх випадках. Більш суттєва різниия за показниками відтворювальної здатності спостерігалася між коровами та їх внучками. 3 а тривалістю сервіс-періоду за першу та кращу лактації вона становила 15,5 (P<0,05) та 33,3 (P<0,001) $і$ міжотельного періоду - 17,3 (P<0,05) та 33,2 дня (P<0,001) відповідно. Між більшістю досліджуваних показників відтворювальної здатності матерів i дочок за першу та вищу лактації співвідносна мінливість була додатною і достовірною, а матерів і внучок - низькою невірогідною $і$ здебільшого від 'ємною (виняток - тривалість тільності). Найвищі додатні коефіцієнти кореляиії спостерігався між тривалістю тільністю корів та їх дочок ( $r=0,131 \pm 0,039$ при $P<0,001)$ і внучок $(r=0,211 \pm 0,088$ при $P<0,05)$ за першу лактацію, a також матерів і дочок за вищу лактаиію $(r=0,114 \pm 0,039$ при $P<0,01)$. Між показниками індиференс-періоду $(r=-0,036-0,051)$ і індексу плодючості корів ( $r=-0,080-0,014)$ та їх нащадків за досліджувані лактації встановлено низькі різнонаправлені недостовірні зв'язки. Встановлено вплив матерів на показники репродуктивної функиії нащадків. Найсуттєвіший вплив вони справляли на тривалість сервіс- $i$ міжотельного періодів, коефіцієнт відтворювальної здатності, вихід телят на 100 корів та індекс осіменіння дочок $\left(\eta_{x}^{2}=27,57-52,22 \%\right)$. За вищу лактаиію ией вплив був значно нижчим (виняток-індекс осіменіння) $-\eta_{x}{ }^{2}=15,39-28,10 \%$.

Ключові слова: корови, дочки, внучки, показники відтворювальної здатності, коефічієнти кореляиії, сила впливу.

\section{Вступ}

При веденні молочного скотарства визначальними критеріями є високий рівень молочної продуктивності корів та добра їх відтворювальна здатність, які є основними господарськи корисними ознаками і які входять до складу комплексного індексу селекційної цінності тварин у країнах з розвиненим молочним скотарством (Caraviello et al., 2006; Van Raden et al., 2011). У селекційно-племінній роботі 3 молочною худобою найбільш цінними є тварини, які поєднують високу продуктивність з добрими репродуктивними ознаками (Caraviello et al., 2006; Proshyna, 2006; Baimishev et al., 2017; Tagesu, 2018).

3 метою поліпшення продуктивних ознак вітчизняної худоби впродовж тривалого часу в Україні використовувався генофонд голштинської породи. 3 кожним наступним поколінням умовна кровність корів вітчизняної худоби за голштинською породою постійно зростає, спричиняючи неоднозначний ефект на показники молочної продуктивності та відтворювальної здатності тварин (Hmel'nychyj and Vechorka, 2018). Численними дослідженнями встановлено, що на фоні підвищення молочної продуктивності та зі зростанням умовної частки спадковості голштинів погіршуються показники відтворювальної здатності, особливо збільшується тривалість сервіс-періоду (Grachev, 2011; Yefimenko et al., 2014; Piddubna, 2014a; Kuziv and Fedorovych, 2016). Зокрема, за повідомленням Л.М. Піддубної (Piddubna, 2014b), вік першого отелення корів української чорно-рябої молочної породи становить 29,4-34,8 місяці, тривалість сервіс-періоду - 139,4-159,6 дня. За даними автора, підвищення надоїв за лактацію на 1000 кг молока призводить до збільшення тривалості сервіс-періоду на 16-28 днів і до зниження коефіцієнта відтворної здатності на 0,03-0,05. Дослідженнями групи вчених на чолі з М.I. Бащенком (Bashhenko et al., 2017) вияв- лено, що в середньому по племінних господарствах України тривалість сервіс-періоду у тварин вищенаведеної породи збільшилася зі 100 днів у 2011 році до 105 днів у 2016 році, а вихід телят на 100 корів знизився $з 80,3$ до 76,9 гол.

Останнім часом у літературних джерелах все частіше з'являються повідомлення про те, що показники відтворювальної здатності тварин зумовлюються генетичними чинниками, такими як належність до породи, типу, генотипу, ліній, походженням за батьком, методу підбору тощо (Bodnar et al., 2014; Shcherbatyj et al., 2015; Yudin et al., 2016; Kuziv and Fedorovych, 2016; Shcherbatyj et al., 2016; Kuznecov, 2016; Shcherbatyj et al., 2017). Однак, недостатньо вивчено вплив матерів на показники відтворювальної здатності корів. Відомо, що вплив материнського організму різноманітний - від середовища ембріонального розвитку теляти до передачі певного генетичного матеріалу. Материнський ефект в селекції сільськогосподарських тварин може бути як позитивним, так і негативним (Nezhlukchenko, 2001).

3 огляду на зазначене, метою нашої роботи було вивчити показники відтворювальної здатності корів української чорно-рябої молочної породи та їх нащадків першого й другого поколінь в умовах ТОВ “Велетень”.

\section{Матеріал і методи досліджень}

Дослідження проведені на коровах української чорно-рябої молочної породи та їх нащадках першого й другого поколінь в умовах ТОВ “Велетень” Глухівського району Сумської області. У корів, на основі ретроспективного аналізу даних (програма управління молочним стадом “Юніформ-Агрі”) та результатів власних досліджень, вивчали вікову динаміку відтворної здатності за першу-сьому та вищу лактації, а у їх дочок і внучок - за першу та вищу лактації. При цьо- 
му враховували такі показники: тривалість лактації, тільності, періоду від отелення до першого осіменіння (індиференс-період), сервіс-періоду, міжотельного періоду, коефіцієнт відтворювальної здатності, вихід телят на 100 корів, індекс осіменіння та індекс плодючості. Тривалість біологічних періодів у корів визначали за загальновідомими методами.

Коефіцієнт відтворювальної здатності (КB3) визначали за формулою Д. Т. Вінничука (Sirac'kyj et al., 2005): $K B 3=\frac{365}{M O \Pi}$,

де 365 - кількість днів у році; МОП - міжотельний період, днів.

Можливий вихід телят (BT) на 100 корів обчислювали за формулою В.Ф. Бочарова (Sirac'kyj et al., 2005): $B T=\frac{365 \times 100}{C+T}$,

де 365 - кількість днів у році; $C$ - середня тривалість сервіс-періоду, днів; $T$ - тривалість тільності, днів.

Індекс плодючості (IП) вираховували за формулою Й. Дохи (Sirac'kyj et al., 2005):

$I \Pi=100-(K+2 \cdot M O \Pi)$,

де $K$ - вік корови при першому отеленні, міс.; МОП - середній міжотельний період, міс.

Коефіцієнти кореляції (r) ознак відтворної здатності між поколіннями тварин, їх характер, напрям i величину вираховували за загальновідомою формулою.

Силу впливу фактора на досліджувані показники визначали шляхом однофакторного дисперсійного аналізу за допомогою програми "Statistica 6.1". Статистичну обробку даних здійснювали за допомогою програмного пакету Microsoft Excel за Г.Ф. Лакиным (Lakyn, 1990). Результати середніх значень вважали статистично вірогідними при $\mathrm{P}<0,05$ (*), $\mathrm{P}<0,01$ $(* *), \mathrm{P}<0,001(* * *)$.

\section{Результати та їх обговорення}

Обов'язковою передумовою рентабельного ведення галузі скотарства $є$ забезпечення високих параметрів відтворення у стадах молочної худоби. Результати наших досліджень свідчать, що відтворювальна здат- ність корів певною мірою зумовлена їх віком (табл. 1). Так, залежно від лактації, тривалість тільності у корів ТОВ "Велетень" коливалася від 278,2 до 280,0, тривалість індиференс-періоду - від 64,4 до 69,0 дня, сервіс-періоду - від 123,5 до 136,4, міжотельного періоду - від 402,2 до 414,8 та сухостійного періоду - від 61,3 до 75,8 дня, коефіцієнт відтворювальної здатності становив 0,91-0,93, вихід телят на 100 корів - 90,9-93,0 гол., індекс осіменіння - 2,41-2,56 та індекс плодючості - 42,2-44,8. Найвищим коефіцієнтом відтворювальної здатності і виходом телят на 100 корів та найкращим індексом плодючості відзначалися корови-первістки, а найменшою тривалістю індиференс-, сервіс- та міжотельного-періодів - корови 3 п’ятою лактацією. Найменший індекс осіменінь було відмічено у тварин з четвертою лактацією. Слід відмітити, що 3 першої до п’ятої лактації спостерігалося деяке покращення окремих показників відтворювальної здатності корів, зокрема, тривалості сервіс- та міжотельного періодів. Так, різниця за цими показниками у корів-первісток та корів 3 другою-п'ятою лактаціями знаходилася в межах 5,3-12,9 (P < 0,05) та 4,9-12,6 дня $(\mathrm{P}<0,05)$ відповідно.

Нами встановлено, що нащадки різних поколінь також відрізнялися за показниками відтворювальної здатності (табл. 2). Зокрема, різниця за тривалістю сервіс-періоду за першу лактацію між матерями та їх дочками становила 24,5, за кращу лактацію - 24,8, за тривалістю міжотельного періоду - 24,8 та 23,7 дня відповідно при $\mathrm{P}<0,001$ в усіх випадках.

Одним із важливих показників, який дає уявлення про відтворювальну здатність тварин, $є$ коефіцієнт відтворювальної здатності. За цим показником за першу лактацію матері поступалися дочкам на 0,04 ( $<<0,001)$, а за кращу - на 0,05 (P <0,001).

У вітчизняній практиці репродуктивну здатність корів на груповому рівні (у межах популяції і року) оцінюють за показником виходу телят на 100 корів. При визначенні цього показника враховується також народжені двійнята, отелення нетелей та корови, що отелилися двічі на рік. За виходом телят на 100 корів кращими знову виявилися дочки. Їх перевага над матерями за цим показником за першу та кращу лактації становила 4,6 гол. (Р <0,001).

\section{Таблиця 1}

Вікова динаміка відтворювальної здатності корів ТОВ “Велетень”

\begin{tabular}{|c|c|c|c|c|c|}
\hline Лактація & $\mathrm{n}$ & Показник & $\mathrm{M} \pm \mathrm{m}$ & $\sigma$ & $\mathrm{Cv}, \%$ \\
\hline \multirow{8}{*}{ I } & \multirow{8}{*}{1739} & Тривалість, днів: тільності & $278,5 \pm 0,20$ & 8,21 & 2,95 \\
\hline & & індиференс-періоду & $69,4 \pm 0,51$ & 21,14 & 30,48 \\
\hline & & сервіс-періоду & $136,4 \pm 2,03$ & 84,76 & 62,16 \\
\hline & & міжотельного & $414,8 \pm 2,03$ & 84,57 & 20,39 \\
\hline & & Коефіцієнт відтворної здатності & $0,91 \pm 0,004$ & 0,15 & 16,32 \\
\hline & & Вихід телят на 100 корів, голів & $90,9 \pm 0,36$ & 14,84 & 16,32 \\
\hline & & Індекс осіменіння & $2,56 \pm 0,043$ & 1,78 & 69,69 \\
\hline & & Індекс плодючості & $44,8 \pm 0,18$ & 7,60 & 16,97 \\
\hline \multirow{5}{*}{ II } & \multirow{5}{*}{1087} & Тривалість, днів: тільності & $278,9 \pm 0,23$ & 7,66 & 2,75 \\
\hline & & сухостійного періоду & $61,3 \pm 0,44$ & 18,35 & 29,91 \\
\hline & & індиференс-періоду & $66,3 \pm 0,42 * * *$ & 13,77 & 20,77 \\
\hline & & сервіс-періоду & $131,1 \pm 2,35$ & 77,60 & 59,20 \\
\hline & & міжотельного періоду & $409,9 \pm 2,36$ & 77,94 & 19,01 \\
\hline
\end{tabular}




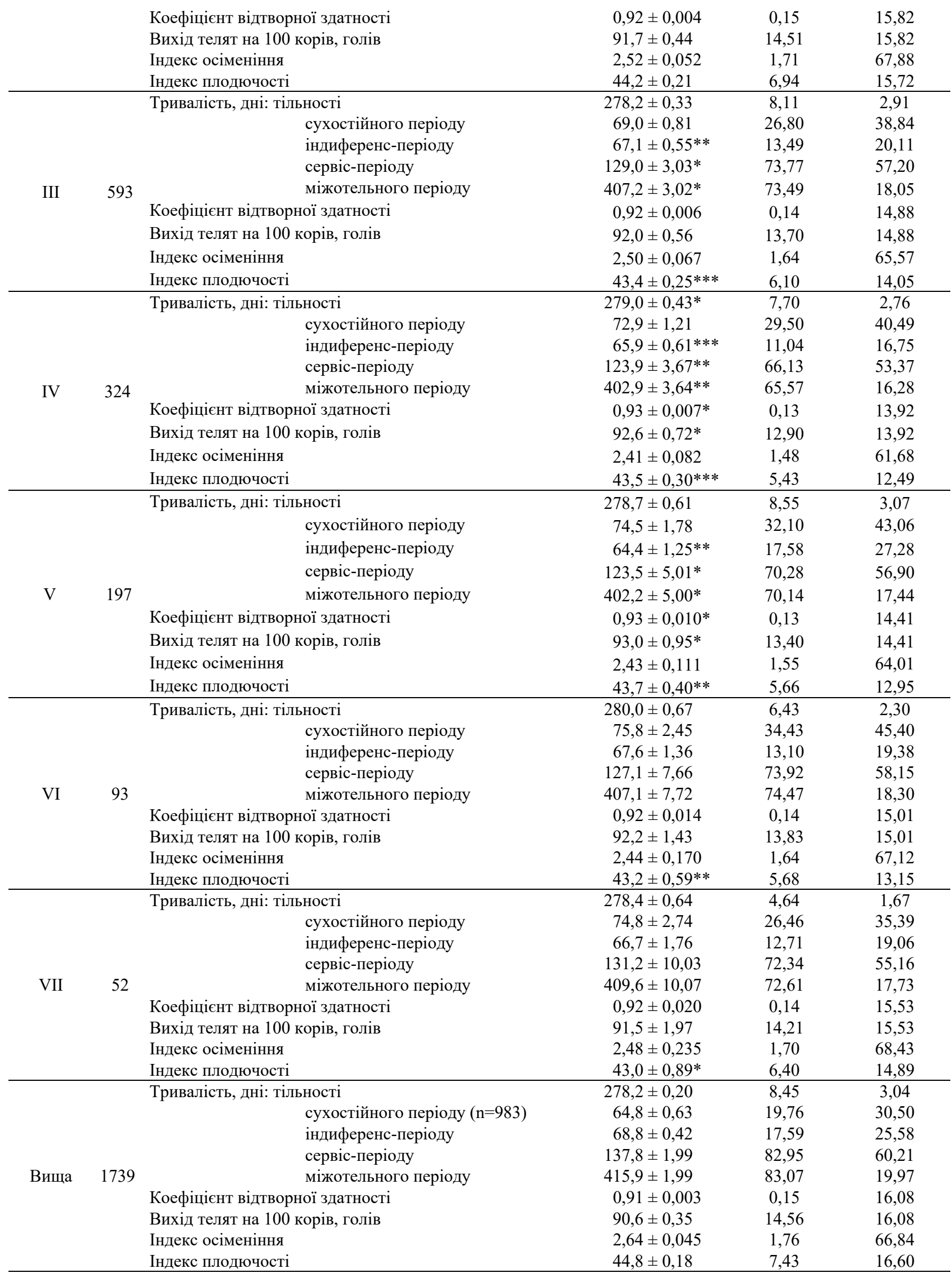

Примітка: достовірність різниці між показниками вказана при порівнянні з першою лактацією

Важливе значення у комплексній оцінці репродуктивної функції тварин має їх плодючість. Отримані нами результати досліджень свідчать, що коровиматері характеризувалися середньою плодючістю, а їх дочки - доброю. Плодючість корів вважається доброю, якщо однойменний індекс становить 48 і більше, середньою - якщо цей індекс знаходиться в межах 41-47 і низькою - якщо його значення не перевищує 
40. Матері за вищенаведеним показником за першу та кращу лактації високовірогідно поступалися своїм дочкам на 7,0 та 6,8. За тривалістю тільності та індиференс-періоду різниця між наведеними групами тварин була несуттєвою, а за індексом осіменіння матері переважали ровесниць за першу лактацію на 0,42, за кращу - на 0,56 при $\mathrm{P}<0,001$ в обох випадках.

\section{Таблиця 2}

Відтворювальна здатність корів і їх дочок за першу та кращу лактації

\begin{tabular}{|c|c|c|c|c|c|}
\hline \multirow{2}{*}{ Показник } & \multirow{2}{*}{$\begin{array}{c}\text { Кількість } \\
\text { пар } \\
\end{array}$} & \multicolumn{2}{|c|}{ Матері } & \multicolumn{2}{|c|}{ Дочки } \\
\hline & & $\mathrm{M} \pm \mathrm{m}$ & $\mathrm{Cv}, \%$ & $\mathrm{M} \pm \mathrm{m}$ & $\mathrm{Cv}, \%$ \\
\hline \multicolumn{6}{|c|}{ Перша лактація } \\
\hline Тривалість, дні: тільності & & $278,9 \pm 0,31$ & 2,79 & $278,7 \pm 0,28$ & 2,54 \\
\hline індиференс-періоду & & $68,7 \pm 1,01$ & 37,31 & $68,6 \pm 0,38$ & 14,06 \\
\hline сервіс-періоду & & $142,6 \pm 3,40$ & 60,67 & $118,1 \pm 2,63$ & 56,67 \\
\hline міжотельного періоду & & $421,5 \pm 3,39$ & 20,49 & $396,7 \pm 2,62$ & 16,81 \\
\hline Коефіцієнт відтворної здатності & 648 & $0,90 \pm 0,006$ & 16,56 & $0,94 \pm 0,005$ & 13,65 \\
\hline Вихід телят на 100 корів, голів & & $89,5 \pm 0,58$ & 16,56 & $94,1 \pm 0,50$ & 13,65 \\
\hline Індекс осіменіння & & $2,65 \pm 0,068$ & & $2,23 \pm 0,062$ & 70,28 \\
\hline Індекс плодючості & & $41,6 \pm 0,27$ & 16,47 & $48,6 \pm 0,21$ & 10,92 \\
\hline \multicolumn{6}{|c|}{ Вища лактація } \\
\hline Тривалість, дні: тільності & & $277,9 \pm 0,36$ & 3,30 & $278,7 \pm 0,29$ & 2,60 \\
\hline індиференс-періоду & & $66,92 \pm 0,64$ & 24,19 & $68,90 \pm 0,39$ & 14,41 \\
\hline сервіс-періоду & & $145,2 \pm 3,29$ & 57,77 & $120,4 \pm 2,71$ & 57,11 \\
\hline міжотельного періоду & & $423,0 \pm 3,31$ & 19,94 & $399,3 \pm 2,71$ & 17,25 \\
\hline Коефіцієнт відтворної здатності & 648 & $0,89 \pm 0,006$ & 16,06 & $0,94 \pm 0,005$ & 13,90 \\
\hline Вихід телят на 100 корів, голів & & $89,0 \pm 0,56$ & 16,06 & $93,6 \pm 0,51$ & 13,90 \\
\hline Індекс осіменіння & & $2,84 \pm 0,067$ & 60,00 & $2,28 \pm 0,062$ & 69,39 \\
\hline Індекс плодючості & & $41,7 \pm 0,26$ & 15,72 & $48,5 \pm 0,22$ & 11,34 \\
\hline
\end{tabular}

Більш суттєва різниця за показниками відтворювальної здатності спостерігалася між коровами та їх внучками (табл. 3). За тривалістю тільності за першу та кращу лактації вона становила відповідно 1,8 (P < $0,05)$ та 0,1 , за тривалістю індиференс-періоду - 3,2 та 1,8 , сервіс-періоду $-15,5(\mathrm{P}<0,05)$ та 33,3 $(\mathrm{P}<0,001)$ і міжотельного періоду $-17,3(\mathrm{P}<0,05)$ та 33,2 дня $(\mathrm{P}<0,001)$. За коефіцієнтом відтворювальної здатності, виходом телят на 100 корів та індексом плодючості за першу лактацію внучки переважали матерів матерів на $0,03(\mathrm{P}<0,05), 3,3$ гол. $(\mathrm{P}<0,01)$ та 6,8 $(\mathrm{P}<$ 0,001), а за кращу лактацію - на 0,07 (P < 0,001), 7,0 гол. $(\mathrm{P}<0,001)$ та 7,7 ( $<0,001)$ відповідно. Більша кількість осіменінь на одне плідне (індекс осіменіння) за вищенаведені лактації відмічено у матерів матерів. За цим показником за першу лактацію вони переважали внучок на 0,20, а за кращу - на 0,76 (P <0,001).

\section{Таблиця 3}

Відтворювальна здатність корів і їх внучок за першу та кращу лактації

\begin{tabular}{|c|c|c|c|c|c|}
\hline \multirow{2}{*}{ Показник } & \multirow{2}{*}{$\begin{array}{c}\text { Кількість } \\
\text { пар }\end{array}$} & \multicolumn{2}{|c|}{ Матері матерів } & \multicolumn{2}{|c|}{ Внучки } \\
\hline & & $\mathrm{M} \pm \mathrm{m}$ & $\mathrm{Cv}, \%$ & $\mathrm{M} \pm \mathrm{m}$ & $\mathrm{Cv}, \%$ \\
\hline \multicolumn{6}{|c|}{ Перша лактація } \\
\hline Тривалість, дні: тільності & & $278,6 \pm 0,67$ & 2,65 & $276,8 \pm 0,60$ & 2,37 \\
\hline індиференс-періоду & & $65,3 \pm 1,53$ & 25,77 & $68,5 \pm 0,88$ & 14,17 \\
\hline сервіс-періоду & & $128,4 \pm 6,23$ & 54,28 & $112,9 \pm 4,92$ & 47,93 \\
\hline міжотельного періоду & 121 & $406,9 \pm 6,45$ & 17,44 & $389,7 \pm 4,99$ & 14,09 \\
\hline Коефіцієнт відтворної здатності & 121 & $0,92 \pm 0,011$ & 14,79 & $0,95 \pm 0,010$ & 12,46 \\
\hline Вихід телят на 100 корів, голів & & $92,0 \pm 1,24$ & 14,79 & $95,3 \pm 1,08$ & 12,46 \\
\hline Індекс осіменіння & & $2,36 \pm 0,116$ & 53,79 & $2,17 \pm 0,117$ & 59,00 \\
\hline Індекс плодючості & & $43,6 \pm 0,51$ & 12,86 & $50,4 \pm 0,37$ & 8,04 \\
\hline \multicolumn{6}{|c|}{ Вища лактація } \\
\hline Тривалість, дні: тільності & & $277,0 \pm 0,92$ & 3,67 & $277,1 \pm 0,59$ & 2,34 \\
\hline індиференс-періоду & & $65,6 \pm 1,30$ & 21,78 & $67,4 \pm 0,77$ & 12,55 \\
\hline сервіс-періоду & & $140,6 \pm 6,10$ & 47,71 & $107,3 \pm 4,55$ & 46,60 \\
\hline міжотельного періоду & 121 & $417,6 \pm 6,26$ & 16,50 & $384,4 \pm 4,59$ & 13,15 \\
\hline Коефіцієнт відтворної здатності & 121 & $0,89 \pm 0,012$ & 14,48 & $0,96 \pm 0,010$ & 11,54 \\
\hline Вихід телят на 100 корів, голів & & $89,4 \pm 1,18$ & 14,48 & $96,4 \pm 1,01$ & 11,54 \\
\hline Індекс осіменіння & & $2,83 \pm 0,128$ & 49,75 & $2,07 \pm 0,111$ & 59,19 \\
\hline Індекс плодючості & & $43,0 \pm 0,47$ & 12,03 & $50,7 \pm 0,35$ & 7,65 \\
\hline
\end{tabular}


Нами була виявлена певна різниця за показниками репродуктивної функції і між дочками та внучками, однак за першу лактацію вона була невірогідною (виняток - індекс плодючості), а за кращу - достовірна різниця (P $<0,05, \mathrm{P}<0,001)$ була встановлена лише за тривалістю сервіс- та міжотельного періодів, коефіцієнтом відтворювальної здатності, виходом телят на 100 корів та індексами осіменіння і плодючості. Варто відмітити, що за всіма досліджуваними показниками відтворювальної здатності кращими виявилися внучки.

Таким чином, результати наших досліджень свідчать, що кожне наступне покоління корів відзначалося кращою відтворювальною здатністю. Мабуть, це можна пояснити своєчасним вибракуванням ялових та стимуляцією неплідних корів, а також покращеним рівнем годівлі.

\section{Таблиця 4}

Зв’язок показників відтворювальної здатності корів та їх нащадків за першу й вищу лактації, $\mathrm{r} \pm \mathrm{m}_{\mathrm{r}}$
Важливе значення у селекції молочної худоби має визначення співвідносної мінливості між окремими ознаками відтворювальної здатності корів та їх нащадків. Аналіз співвідносної мінливості показав різний рівень та напрям зв'язків показників відтворювальної здатності матерів $з$ цими ж показниками їх дочок i внучок (табл. 4).

За першу та вищу лактації між більшістю досліджуваних показників відтворювальної здатності корів та їх дочок зв'язки були додатні і майже у всіх випадках вірогідні. Залежно від показника та лактації вони знаходилися в межах 0,012-0,131, причому найвищими вони були між тривалістю тільності, коефіцієнтом відтворювальної здатності та виходом телят на 100 корів, а найнижчими - за індексом плодючості та тривалістю індиференс-періоду.

\begin{tabular}{|c|c|c|c|c|}
\hline \multirow[t]{2}{*}{ Показник } & \multicolumn{2}{|c|}{$\begin{array}{c}\text { Кореляція показників відтворюва- } \\
\text { льної здатності корів за першу } \\
\text { лактацію з цими показниками у їх: }\end{array}$} & \multicolumn{2}{|c|}{$\begin{array}{c}\text { Кореляція показників відтворюваль- } \\
\text { ної здатності корів за вищу лактацію } \\
3 \text { цими показниками у їх: }\end{array}$} \\
\hline & дочок $(\mathrm{n}=648)$ & внучок $(\mathrm{n}=121)$ & дочок $(\mathrm{n}=648)$ & внучок (n=121) \\
\hline Тривалість: тільності & $0,131 \pm 0,039^{3}$ & $0,211 \pm 0,088^{1}$ & $0,114 \pm 0,039^{2}$ & $0,055 \pm 0,091$ \\
\hline індиференс-періоду & $0,023 \pm 0,039$ & $-0,036 \pm 0,092$ & $0,022 \pm 0,039$ & $0,051 \pm 0,091$ \\
\hline сервіс-періоду & $0,085 \pm 0,039^{1}$ & $-0,097 \pm 0,091$ & $0,087 \pm 0,039^{1}$ & $-0,068 \pm 0,091$ \\
\hline міжотельного періоду & $0,082 \pm 0,039^{1}$ & $-0,069 \pm 0,091$ & $0,083 \pm 0,039^{1}$ & $-0,033 \pm 0,092$ \\
\hline Коефіцієнт відтворної здатності & $0,127 \pm 0,039^{3}$ & $-0,033 \pm 0,092$ & $0,121 \pm 0,039^{2}$ & $0,025 \pm 0,092$ \\
\hline Вихід телят на 100 корів & $0,127 \pm 0,039^{3}$ & $-0,033 \pm 0,092$ & $0,121 \pm 0,039^{2}$ & $0,025 \pm 0,092$ \\
\hline Індекс осіменіння & $0,105 \pm 0,039^{2}$ & $-0,008 \pm 0,092$ & $0,102 \pm 0,039^{2}$ & $-0,032 \pm 0,092$ \\
\hline Індекс плодючості & $0,014 \pm 0,039$ & $-0,060 \pm 0,091$ & $0,012 \pm 0,039$ & $-0,080 \pm 0,091$ \\
\hline
\end{tabular}

Таблиця 5

Сила впливу $\left(\eta_{\mathrm{x}}^{2}\right)$ корів на відтворювальну здатність нащадків за першу та вищу лактації, \%

\begin{tabular}{|c|c|c|c|c|}
\hline \multirow[t]{2}{*}{ Показник } & \multicolumn{2}{|c|}{$\begin{array}{c}\text { Сила впливу корів на показники } \\
\text { відтворювальної здатності за першу } \\
\text { лактацію: }\end{array}$} & \multicolumn{2}{|c|}{$\begin{array}{c}\text { Сила впливу корів на показники } \\
\text { відтворювальної здатності за вищу } \\
\text { лактацію: }\end{array}$} \\
\hline & дочок $(\mathrm{n}=648)$ & внучок $(\mathrm{n}=121)$ & дочок $(\mathrm{n}=648)$ & внучок $(\mathrm{n}=121)$ \\
\hline Тривалість: тільності & 36,71 & 15,86 & $59,99^{2}$ & 12,45 \\
\hline індиференс-періоду & 6,14 & 1,53 & $45,94^{1}$ & 1,61 \\
\hline сервіс-періоду & 52,22 & 6,87 & 15,56 & 9,28 \\
\hline міжотельного періоду & 46,72 & 6,21 & 15,39 & 9,39 \\
\hline Коефіцієнт відтворювальної здатності & 37,49 & 5,54 & 28,10 & 6,34 \\
\hline Вихід телят на 100 корів & 37,49 & 5,54 & 28,10 & 6,34 \\
\hline Індекс осіменіння & 27,57 & 8,13 & 29,53 & 7,64 \\
\hline Індекс плодючості & 3,72 & 6,68 & $43,91^{1}$ & 9,82 \\
\hline
\end{tabular}

Коефіцієнти кореляції між досліджуваними показниками репродуктивної здатності корів та їх внучок були низькими невірогідними і здебільшого від’ємними, що вказує, на нашу думку, на низьку успадковуваність ознак відтворювальної функції.

Дисперсійний аналіз свідчить, що корови суттєвіший вплив справляли на показники відтворювальної здатності дочок, ніж внучок (табл. 5). Так, сила впливу матерів на показники репродуктивної функції дочок за першу лактацію знаходилася в межах 3,7252,22, за кращу - 15,39-59,99, а внучок - відповідно в межах $1,53-15,86$ та $1,61-12,45 \%$.

\section{Висновки}

1. Встановлено, що відтворювальна здатність корів певною мірою зумовлена їх віком. Залежно від лактації, тривалість тільності у них становила 278,2-280,0, індиференс-періоду - 64,4-69,0, сервіс-періоду 123,5-136,4, міжотельного періоду - 402,2-414,8 i сухостійного періоду - 61,3-75,8 дня, коефіцієнт відтворювальної здатності - 0,91-0,93, вихід телят на 100 корів - 90,9-93,0 гол., індекс осіменіння - 2,41-2,56 та індекс плодючості - 42,2-44,8. Слід відмітити, що 3 першої до п'ятої лактації спостерігалося деяке покращення окремих показників відтворювальної здатно- 
сті корів, зокрема, тривалості сервіс- та міжотельного періодів.

2. Встановлено, що кожне наступне покоління корів відзначалося кращою відтворювальною здатністю, що, на нашу думку, пояснюється своєчасним вибракуванням ялових та стимуляцією неплідних корів, а також покращеним рівнем годівлі. Різниця за тривалістю сервіс-періоду за першу й вищу лактації між коровами та їх дочками становила 24,5 й 24,8 , за тривалістю міжотельного періоду - 24,8 й 23,7 дня при $\mathrm{P}<0,001$ в усіх випадках, а між коровами та їх внучками - 15,5 (Р<0,05) й 33,3 (P<0,001) та 17,3 $(\mathrm{P}<0,05)$ й 33,2 дня $(\mathrm{P}<0,001)$ відповідно.

3. Між більшістю досліджуваних показників відтворювальної здатності матерів і дочок за першу та вищу лактації співвідносна мінливість була додатною і достовірною, а матерів і внучок - низькою невірогідною і здебільшого від'ємною (виняток - тривалість тільності). Найвищі додатні коефіцієнти кореляції спостерігався між тривалістю тільністю корів та іх дочок $(\mathrm{r}=0,131 \pm 0,039$ при $\mathrm{P}<0,001)$ і внучок $(\mathrm{r}=0,211 \pm 0,088$ при $\mathrm{P}<0,05)$ за першу лактацію, а також матерів і дочок за вищу лактацію $(\mathrm{r}=0,114 \pm$ $0,039$ при $\mathrm{P}<0,01)$. Між показниками індиференсперіоду ( $\mathrm{r}=-0,036-0,051)$ і індексу плодючості корів $(\mathrm{r}=-0,080-0,014)$ та їх нащадків за досліджувані лактації встановлено низькі різнонаправлені недостовірні зв'язки.

4. Встановлено вплив матерів на показники репродуктивної функції нащадків. Найсуттєвіший вплив вони справляли на тривалість сервіс- і міжотельного періодів, коефіцієнт відтворювальної здатності, вихід телят на 100 корів та індекс осіменіння дочок $\left(\eta_{\mathrm{x}}{ }^{2}=27,57-52,22 \%\right)$. За вищу лактацію цей вплив був значно нижчим (виняток - індекс осіменіння) $\eta_{\mathrm{x}}^{2}=15,39-28,10 \%$.

Перспективи подальших досліджень. У наступних дослідженнях буде вивчатися особливості росту живої маси у молодому віці корів української чорнорябої молочної породи та їх нащадків першого й другого поколінь в умовах ТОВ “Велетень”.

\section{References}

Baimishev, M.H., Eremin, S.P., Plemiashov, K.V., Zaitsev, V.V., Baimishev, H.B., \& Safiullin, H.A. (2017). Connection of Reproductive Indices of HighProductive Cows with Duration of Their Dead-Wood Period. Biomedical \& Pharmacology Journal, 10(4), 2145-2151. doi: 10.13005/bpj/1339.

Bashhenko, M.I. Gladij, M.V., Mel'nyk, Yu.F., Yefimenko, M.Ya., Krugljak, A.P., Polupan, Yu.P., Vyshnevs'kyj, L.V., Birjukova, O.D., Krugljak, O.V., Kuzebnyj, S.V., \& Pryjma, S.V. (2017). Stan i perspektyvy rozvytku molochnogo skotarstva Ukrai'ny. Rozvedennja i genetyka tvaryn, 54, 6-14. http://digest.iabg.org.ua/images/digest/54/Animal_bre eding_and_genetics_54.pdf (in Ukrainian).

Bodnar, P.V., Shcherbatyj, Z.Y., \& Fedorovych, E.I. (2014). Vplyv genotypu na vidtvornu zdatnist' tvaryn. Biologija tvaryn, $16 \quad$ (3), 17-22. http://aminbiol.com.ua/index.php/101-bt-16-32014/701 (in Ukrainian).

Caraviello, D.Z., Weigel, K.A., Fricke, P.M., Wiltbank, M.C., Florent, M.J., Cook, N.B., Nordlund, K.V., Zwald, N.R., \& Rawson C. L. (2006). Survey of Management Practices on Reproductive Performance of Dairy Cattle on Large US Commercial Farms. J. Dairy Sci., 89, 4723-4735. doi: 10.3168/jds.S00220302(06)72522-X.

Grachev, V.S. (2011). Vozrastnaja dinamika produktivnyh i vosproizvoditel'nyh kachestv vysokoproduktivnogo molochnogo skota. Molochnohozjajstvennyj vestnik, 1, 28-30 (in Russian).

Hmel'nychyj, L.M., \& Vechorka, V.V. (2018). Vplyv chastky spadkovosti golshtyns'koi' porody ta metodiv pidboru na gospodars'ky korysni oznaky koriv molochnoi' hudoby. Rozvedennja i genetyka tvaryn, 55, 135-142. http://digest.iabg.org.ua/selection/item/203955-019 (in Ukrainian).

Yefimenko, M., Podoba, B., \& Bratushka, R. (2014). Perspektyvy rozvytku ukrai'ns'koi' chorno-rjaboi' molochnoi' porody. Tvarynnyctvo Ukrai'ny, 10, 1014. http://nbuv.gov.ua/UJRN/TvUkr_2014_10_5 (in Ukrainian).

Yudin, V.M., Ljubimov, A.I., Nikitin, K.P. (2016). Selekcija cherno-pestroj porody krupnogo rogatogo skota $\mathrm{s}$ ispol'zovaniem razlichnyh metodov plemennogo podbora. Izvestija Samarskoj gosudarstvennoj sel'skohozjajstvennoj akademii, 1, 37-40. doi: 10.12737/18326 (in Russian).

Kuziv, M.I., \& Fedorovych, E.I. (2016). Reppoductive ability of ukrainian black and white dairy cows. Scientific Messenger LNUVMBT named after S.Z. Gzhytskyj, 18, 2(67), 120-123. doi: $10.15421 /$ nvlvet6727.

Kuznecov, V.M. (2016). Vosproizvoditel'naja sposobnost' korov i selekcija po molochnoj produktivnosti. Mezhdunarodnyj nauchno-issledovatel'skij zhurnal, 4 (46), 6, 50-52. doi: 10.18454/IRJ.2016.46.280 (in Russian).

Lakyn, H.F. (1990). Byometryia: uchebnoe posobye [dlia byol. spets. vuzov]. M.: Vysshaia shkola (in Russian).

Mucha, S., \& Strandberg, E. (2011). Genetic analysis of milk urea nitrogen and relationships with yield and fertility across lactation. J. Dairy Sci., 94 (11), 56655672. doi: 10.3168/jds.2010-3916.

Nezhlukchenko, T.I. (2001). Vykorystannja materyns'kogo efektu v selekcii' sil's'kogospodars'kyh tvaryn. Genetyka i selekcija v Ukrai'ni na mezhi tysjacholit'. K.: Logos, 4, 281-285 (in Ukrainian).

Piddubna, L.M. (2014a). Holsteinization of open regional population of black-and-white cattle and prospects of its further improvement. The Animal Biology, 16(4), 121-132. doi: 10.15407/animbiol16.04.

Piddubna, L.M. (2014b). Molochna produktyvnist' ta vidtvorna zdatnist' koriv ukrai'ns'koi' chorno-rjaboi' molochnoi' porody providnyh plemzavodiv pivnichnopolis'kogo regionu. Visnyk Sums'kogo nacional'nogo agrarnogo universytetu, 7(26), 55-58. http://nbuv.gov.ua/UJRN/Vsna_tvar_2014_7_13 (in Ukrainian). 
Proshyna, A. (2011). Vosproyzvodstvo stada: poterjannaja stranyca. Zhyvotnovodstvo Rossyy. 9, 40-41 (in Russian).

Shcherbatyj, Z.Y., Bodnar, P.V., \& Kropyvka, Y.G. (2017). Milk productivity and reproductive ability of ukrainian black-spotted dairy breed cows of different type of constitution. Scientific Messenger LNUVMBT named after S.Z. Gzhytskyj, 19(74), 182-187. doi: 10.15421/nvlvet7440.

Shcherbatyj, Z.Y., Bodnar, P.V., \& Bodnaruk, V.Y. (2015). Reproductive ability of heifers and cows firstborn of ukrainian black spotted dairy breed with different lines. Scientific Messenger of LNU of Veterinary Medicine and Biotechnologies, 17(1), 286-293. https://nvlvet.com.ua/index.php/journal/article/view/44 7.

Shcherbatyj, Z.Y., $\quad$ Kozenko, O.V., $\quad$ Bodnar, P.V., \& Bodnaruk, V.Y. (2016). Reproductive ability of heifers and cows firstborn of ukrainian black spotted dairy breed with different origin. Scientific Messenger of LNU of Veterinary Medicine and Biotechnologies, 18(1), 177-184. https://nvlvet.com.ua/index.php/ journal/article/view/154.

Sirac'kyj, J. Z., Fedorovych, E. I., Kadysh, V. O. (2005). Metody ocinky vidtvornoi' zdatnosti hudoby. Metodyky naukovyh doslidzhen' iz selekcii', genetyky ta biotehnologii' u tvarynnyctvi. K.: Agrarna nauka, 175-178 (in Ukrainian).

Tagesu, A. (2018). Review on the Reproductive Health Problem of Dairy Cattle. Journal of Dairy and Veterinary Sciences, 5(1), 1-12. doi: 10.19080/ JDVS.2018.05.555655.

Van Raden, P.M., Olson, K.M., Null, D.J., Hutchison, J.L. (2011). Harmful recessive effects on fertility detected by absence of homozygous haplotypes. J. Dairy Sci., 94(12), 6153-6161. doi: $10.3168 /$ jds.2011-4624. 